IZA DP No. 7287

Employment Effects of Low-Skilled Immigrants in Korea

Jungho Kim

March 2013

Forschungsinstitut zur Zukunft der Arbeit Institute for the Study of Labor 


\title{
Employment Effects of Low-Skilled Immigrants in Korea
}

\author{
Jungho Kim \\ Ajou University \\ and IZA
}

\section{Discussion Paper No. 7287 \\ March 2013}

\author{
IZA \\ P.O. Box 7240 \\ 53072 Bonn \\ Germany \\ Phone: +49-228-3894-0 \\ Fax: +49-228-3894-180 \\ E-mail: iza@iza.org
}

Any opinions expressed here are those of the author(s) and not those of IZA. Research published in this series may include views on policy, but the institute itself takes no institutional policy positions. The IZA research network is committed to the IZA Guiding Principles of Research Integrity.

The Institute for the Study of Labor (IZA) in Bonn is a local and virtual international research center and a place of communication between science, politics and business. IZA is an independent nonprofit organization supported by Deutsche Post Foundation. The center is associated with the University of Bonn and offers a stimulating research environment through its international network, workshops and conferences, data service, project support, research visits and doctoral program. IZA engages in (i) original and internationally competitive research in all fields of labor economics, (ii) development of policy concepts, and (iii) dissemination of research results and concepts to the interested public.

IZA Discussion Papers often represent preliminary work and are circulated to encourage discussion. Citation of such a paper should account for its provisional character. A revised version may be available directly from the author. 


\section{ABSTRACT}

\section{Employment Effects of Low-Skilled Immigrants in Korea*}

This study examines the impact of inflows of foreign workers on Korean natives' economic performance - namely, employment - through the Employment Permit System, the basis of Korea's system by which to introduce low-skilled immigrants. Using National Employment Insurance data, analyses reveal that the adjustment cost related to the introduction of foreign workers was not substantial over the 2004-2005 period. However, a substitution effect exists between the employment of foreign and native workers in the service industry and among less-educated natives. The results suggest that policy assistance is needed to lessen the impacts caused by inflows of foreign workers and to enhance adjustments within the labor market on a sector-by-sector basis.

JEL Classification: F22, J61, J63

Keywords: employment permit system, low-skilled immigrants, employment of natives, adjustment costs

Corresponding author:

Jungho Kim

College of Social Sciences

Ajou University

San 5, Woncheon-dong, Yeongtong-gu

Suwon 443-749

Korea

E-mail: jungho@ajou.ac.kr

\footnotetext{
* The author would like to thank Gyeongjoon Yoo, Hisam Kim and colleagues at Korea Development Institute for useful comments and suggestions. All remaining errors belong solely to the author. This work was supported by the National Research Foundation of Korea Grant funded by the Korean Government (NRF-2012S1A5A8025057).
} 


\section{Introduction}

Although Korea is not a traditional destination for immigrants, inflows of foreign labor have seen a rapid increase since the late 1980s. The number of foreign workers increased from around 20 thousands in 1990, to 307 thousands in 2000 and 691 thousands in 2009 . Theoretically, if socio-cultural costs are excluded, inflows of foreign workers would help distribute economic resources in a more effective manner, so that natives' total income should rise. However, while native workers and capitalists complementary to foreign workers earn benefits, native workers whom foreign workers replace suffer losses; hence, there is room for government intervention. This study analyzes the impacts on Korean natives' economic performance—namely, employment—of inflows of foreign workers through the Employment Permit System(EPS), the basis of Korea's system by which to introduce low-skilled immigrants into the country.

Most studies that examine how immigrants affect the employment levels of native workers in a host country tend to focus on geographical variations (Borjas et al., 1997; Card, 2001; Angrist and Kugler, 2003; Dustman et al., 2005). While interpretations of the spatial correlation approach are intuitive, their implications vis-à-vis the adjustment process are limited. For example, even if the natives' level of employment remained unchanged with inflows of immigrants into a local labor market, those who lose their jobs may differ quite markedly from those who obtain jobs. Alternatively, the current study measures the impact of foreign workers on the job experience of native workers at the firm level, following Malchow-Møller et al. (2009); it bears the advantage of estimating separately those impacts on changes of job and on job losses, which are likely to generate different implications vis-àvis adjustment cost. 
Taking a meta-analysis of the existing literature, Longhi et al. (2008) conclude that inflows of foreign workers might have a negative impact on natives’ performance, but that its magnitude is likely to be small. However, it should be noted that the relationship between the employment of foreign workers and that of domestic workers in a labor market depends on a variety of factors, including the production technology, institutions, and skill levels of foreign workers. Therefore, a sound immigration policy requires a body of evidence on the local labor market. Studies of the Korean labor market, however, are quite limited. Cho (2004) shows that foreign workers complemented natives, using 2002 firm-level survey data. Hahn and Choi (2006) argue that male semi-skilled natives tended to be replaced by foreign workers under the Industrial Trainee System between 1997 and 2001. The current study is the first to evaluate Korea’s EPS, introduced in 2004.

Analysis of National Employment Insurance (NEI) data reveals that adjustment costs incurred as a result of the introduction of foreign workers were not substantial over the August 2004-December 2005 period. However, according to sector-based analysis, a substitution effect exists between the employment of foreign and native workers in the service industry. In terms of skill levels, substitutability exists between foreign workers and natives with less than a high school diploma. Policy is needed to mitigate the impacts caused by inflows of foreign workers and enhance sector-based adjustments within the labor market.

The remainder of the paper is organized as follows. Section II provides institutional background information. Section III reviews the theoretical discussions and results of previous studies. Sections IV and V introduce the statistical model and data used, respectively. Section VI presents our empirical results, while Section VII summarizes the analysis and discusses policy implications. 


\section{Institutional Background}

Korean policy on foreign labor has predominantly been about managing low-skilled workers. ${ }^{1}$ In response to the growing shortage of labor in 3D (“difficult, dirty, dangerous”) industries in the late 1980s, the government introduced the Industrial Technology Trainee System in 1991, under which a foreign laborer could work as a trainee for six months, with a possible six-month extension. The system was overhauled as the Industrial Trainee System (ITS) in 1993, offering one-year contracts, each with a one-year extension. The system was further expanded in 2000 as the Training and Employment System, and it allowed for one year of employment after a two-year training period. Under ITS, various issues_-including illegal residency and the human rights of foreign workers-were addressed, leading to the introduction in 2004 of EPS. EPS ensures the fundamental rights of labor for foreign employees and the right of employers to hire them. EPS incorporated ITS in 2007 and is currently the main foreign labor policy in Korea. ${ }^{2}$

EPS works as follows. Each year the committee on foreign migration policy determines the size of the foreign labor force, the industries involved, and the laborers' source countries. Employment contract terms and legal rights are specified through memoranda of understanding (MOU) with source countries, and no private institution is involved in the

\footnotetext{
${ }^{1}$ The definition of "low-skilled labor" may be based on the education, wage, or skill level required for a job (OECD, 2009). We follow the definition based on skill level, but in practice make a distinction through the visa type in Immigration Law (Yoo and Lee, 2009). Low-skilled foreign workers consist of those with visa types for Industrial Trainees (D-3, E-8), General Foreign Workers (E-9), and Overseas Koreans (H-2). Most of them are occupied as craftsmen, service and sales persons, and basic laborers in the manufacturing, construction, accommodation, and food service industries. High-skilled workers refer to those with visa types for Professors (E1), Language Instructors (E2), Researchers (E3), Technical Instructors (E4), Professionals (E5), Artists (E6), and Special Activities (E7).

2 Another branch of foreign migration policy pertains to overseas Koreans, which is incorporated into EPS since 2007. Refer to Kim (2008) for the detailed history of two tracks of immigration policy in Korea.
} 
process. $^{3}$ The source country's government provides the Korean government with a list of job applicants. To receive a foreign worker permit, an employer looking for foreign workers needs to prove that there is no native applicant for a specific job, following more than seven days of advertisement. The employment service center then recommends individuals from among the list of foreign job applicants, and the employer decides whom to hire within three months of the application date; the employment service center issues an employment permit, and the employer offers a contract within three months of the issue date.

The contract duration is less than one year, but is renewable to three years from the date of entry. The maximum contract duration was extended in October 2009 to five years, upon the employer's request after three initial years. Foreign employees enjoy the same labor law protections as natives and have the right to be covered by the four major social insurance programs (i.e., health, pension, employment, and industrial accident compensation). NEI coverage was mandatory until 2005, but has been optional since.

The foreign labor force in Korea as a percentage of the total force increased from $1.40 \%$ in 2000 to $2.87 \%$ in 2009; the ratio of foreign residents to the native population increased from $1.02 \%$ to $2.29 \%$ during the same period (see <Figure $1>$ ). ${ }^{4}$ Further, low-skilled workers comprised about $94 \%$ of all foreign workers in 2009; in that year, among low-skilled foreign workers with legal status, about one-third were those under a general Employment Permit, and about two-thirds were overseas Koreans under a special Employment Permit.

\footnotetext{
${ }^{3}$ In 2004, Korea had MOU with 7 countries: China, Indonesia, Mongolia, the Philippines, Sri Lanka, Thailand, and Vietnam. By 2009, Korea additionally had MOU with 8 countries: Bangladesh, Cambodia, East Timor, Kyrgyzstan, Myanmar, Nepal, Pakistan, and Uzbekistan.

${ }^{4}$ The size of the foreign labor force is estimated by adding the number of foreign residents with an illegal status to that of those with valid employment visas (Lee and Park, 2008). The employment visa includes Short-term Employment (C-4), Industrial Trainees (D-3), Business Investment Trainee (D-8), Employment (E), Employment Management (F-14), and Visiting Employment (H-2).
} 


\section{Theoretical Discussion and Hypotheses}

Answers to the question of how inflows of foreign workers affect natives' economic opportunities essentially depend on differences in human capital between the two groups and the characteristics of a capital market (Borjas, 1999). Suppose that the labor force consists of skilled and unskilled workers and that the capital supply is fixed. When unskilled foreign workers arrive in an economy, both the total labor supply and the share of unskilled labor increase. As a result, both the wages of skilled workers and interest rates increase, whereas the wages of unskilled workers decrease. Concurrently, the employment levels of skilled laborers increase, while those of unskilled laborers decrease. ${ }^{5}$ Since skilled labor, unskilled labor, and capital complement each other, the total compensation among these three factors increases.

In summary, when the social cost of assimilating immigrants is not considered, inflows of unskilled immigrants can increase the total income of natives, but the income distribution among production factors changes. ${ }^{6}$ Both skilled native workers and capitalists complementary to foreign workers benefit, while the unskilled natives replaced by foreign workers lose. Since the skill level of a worker tends not to change markedly in the short term, it is important to monitor who bears adjustment costs relating to inflows of immigrants.

As mentioned, the literature that examines the effect of immigrants on natives' employment levels tends to focus on geographical variations (Borjas et al., 1997; Card, 2001; Angrist and Kugler, 2003; Dustman et al., 2005). As Borjas (1999) points out, this approach is likely to

\footnotetext{
5 The implication for employment remains the same when the capital market is open.

6 Although the cost related to the assimilation of immigrants needs to be reviewed in various aspects, it is worth noting that the migration settlement in Korea is few compared to states in Europe (Seol and Skrentny, 2009).
} 
generate estimation bias, for two reasons. First, immigrants can choose where to be among various labor markets, depending on their expected opportunities. Second, natives may respond to inflows of immigrants by moving their labor or capital and thus maximizing their utilities. Fixed-effect models and instrumental variables (IVs) methods are often employed to deal with these issues. In the literature, the IVs that predict inflows of immigrants include the number of foreign workers or their share in the local labor force in the initial period (Altonji and Card, 1991; Card, 2001).

Interpretations of the spatial correlation approach are intuitive, but its implications with regard to the adjustment process are limited. Alternatively, the current study measures the impact of foreign workers on the employment of native workers at the firm level (MalchowMøller et al., 2009). As mentioned, this study has the advantage of estimating, separately, the impacts vis-à-vis changes of job and job losses-two aspects that are likely to generate different adjustment cost implications. There remains the issue that foreign workers' employment levels at the firm level are endogenous to the job stability of individual workers, and that this is addressed by considering IVs and individual fixed-effects models.

While a body of international evidence suggests that foreign worker inflows are likely to have a small impact on natives’ economic opportunities (e.g., Longhi et al., 2008), it is still critical to understand their consequences in a specific labor market. In this regard, studies of the Korean labor market are quite limited. By estimating the production function at the firm level, Cho (2004) concludes that foreign workers complement natives; however, his analysis is constrained, as it is based on the cross-sectional data of the 2002 Foreign Workers Employment Survey. Using Small and Medium-sized Enterprises Survey data (1997-2001), Hahn and Choi (2006) estimated the impact of foreign workers on the employment and wages 
of natives, by gender and skill level. They argue that male semi-skilled natives (e.g., machine operators and assemblers) tend to be replaced by foreign workers through the Industrial Trainee System. This study, however, focuses on EPS, the country's main foreign labor policy since 2004.

One hypothesis under investigation is that there exists a substitution effect in the employment of foreign workers and natives in the Korean labor market. As discussed by Malchow-Møller et al. (2009), there are two cases of substitution. In the first case, called displacement, a native loses a job as a result of the employment of a foreign worker. In the second case, replacement, a foreign worker is hired after a native leaves his or her job. Although displacement and replacement effects are distinguished in theory, they are not identified empirically; this is because it is difficult to determine whether employment of a foreign worker precedes job separation by a native, or vice versa. The empirical analysis below hinges on the timing of event observations, but caution is needed: the timing of actual decisions may differ from those of the related observations. The other hypothesis considers that the employment of foreign workers complements that of natives; with complementarity, foreign and native workers are jointly hired.

\section{Statistical Model}

To estimate the effect of foreign workers' level of employment on the probability of job separation by natives in the workplace, a duration model is considered. Specifically, we employ a competing risks model, where unemployment and job changes are treated as two mutually exclusive events (Sueyoshi, 1992).

The model is a discrete duration model, and the time-period unit is one month. The 
employment status of a worker in each period is observed, and the probability of job separation is defined over each period, $\{[0,1),[1,2), \ldots[t,-1, t),[t, \infty)\}$. There are two kinds of separation: job change $(e)$ and unemployment $(u)$; a random variable, $T_{k}$, is defined as the duration for each event $(k=e, u)$. Since only the first event is observed in one employment spell, the observed failure time, $T$, is the minimum of the durations of the two events ( $\left\{T=\min \left\{T_{e}, T_{u}\right\}\right.$ ). When the segment from time $t-1$ to time $t$ is defined as period $t$, the conditional hazard that a worker moves to status $j$ at period $t, h_{i t}$, can be expressed as follows: $h_{j t}=h_{j}\left(t \mid X_{j t}, v_{i}\right)=\operatorname{Pr}\left(t-1 \leq T_{i}<t \mid T_{k} \geq t-1, \forall k=e, u, X_{j t}, v_{i}\right)$ for $j=e, u$.

In equation (1), $X_{j t}$ denotes the observable characteristics at period $t$, including the age, gender, education, experience, and employment level of foreign workers in the workplace. An unobserved individual characteristic, $v_{j}$, represents a worker's ability, confidence, or social network, any of which may correlate with the probability of job separation $j$. Two kinds of unobserved individual characteristics, $v_{e}$ and $v_{u}$, are assumed to be constant over time and to correlate.

The data contain three kinds of employment spells. The first is a censored observation where a worker is seen as being employed from the initial period to the last. The second and third are those that end with job changes or unemployment. The contribution of one spell to the likelihood is the product of the conditional probabilities over the periods of observation, as follows:

$$
L_{A}\left(t \mid X_{1}, \ldots X, v_{e}, v_{u}\right)=h_{e t}^{d_{e}} h_{u t}^{d_{u}}\left\{\left(1-h_{e t}\right)\left(1-h_{u t}\right)\right\}^{\left(1-d_{e}-d_{u}\right)} \prod_{i=e, u \tau} \prod_{\tau=1}^{t-1}\left(1-h_{j \tau}\right),
$$

where $d_{e}$ and $d_{u}$ are index functions indicating that the job spells ended with job change and unemployment, respectively. When the joint cumulative distribution function of $v_{e}$ and $v_{u}$ are 
denoted as $F\left(v_{e}, v_{u}\right)$, the contribution of one job spell is expressed as follows:

$L=\iint_{v_{e}, v_{u}} L_{A}\left(t \mid X_{1}, \ldots X, v_{e}, v_{u}\right) d F\left(v_{e}, v_{u}\right)$.

It is assumed that measures of individual heterogeneity with respect to the hazards of transition $-v_{e}$ and $v_{u}$-follow the multivariate normal distribution.

$\left(\begin{array}{l}v_{e} \\ v_{u}\end{array}\right) \sim N\left(\left(\begin{array}{l}0 \\ 0\end{array}\right),\left(\begin{array}{cc}\sigma_{e}^{2} & \rho_{e u} \\ \rho_{\text {eu }} & \sigma_{u}^{2}\end{array}\right)\right)$.

In the estimation, the hazard in each period is specified as Probit functions. ${ }^{7}$

$h_{j t}=\Phi\left(\lambda_{i}^{0}(t)+X_{j} \beta_{i}+v_{i}\right)$ for $j=e, u$.

In equation (5), $\Phi(\cdot)$ is the cumulative probability function of the standard normal distribution and $\lambda_{j}^{0}(t)$ implies the baseline hazard. The estimation of the parameters, $\left\{\beta_{e}, \beta_{u}, \sigma_{e}, \sigma_{u}, \rho_{e u}\right\}$, is performed by searching for the maximizers of the likelihood in equation (3) over all the employment spells in the data.

The key explanatory variable is the employment of foreign workers in a workplace; two measures are considered. One is the share of foreign workers among all employees in workplace $l$ at period $t, F W_{l t}=F_{l t} /\left(N_{l t}+F_{l t}\right)$, and its coefficient should be interpreted as the effect of the workplace characteristics associated with the employment of foreign workers. The other is the change in the share, $\Delta F W_{l t+1}=\left(F_{l t+1}-F_{l t}\right) /\left(N_{l t}+F_{l t}\right)$. In principle, the change in the foreign worker employment level prior to the job separation event should be measured between time $t-1$ and time $t$; however, it takes about two to three months for an employer to hire a foreign worker, following application under EPS in Korea. Therefore, it is assumed that the level of employment of foreign workers at period $t+1$ precedes job

\footnotetext{
7 The main estimation results below remain qualitatively the same when the hazard function is assumed to be a linear function.
} 
separation at period $t$.

If the hiring of foreign workers in a workplace has a displacement effect, the increase in the share of foreign workers will increase the hazards of both job changes and unemployment, resulting in a positive coefficient. On the other hand, the positive sign of the coefficient on the change in the share of foreign workers may reflect a replacement effect, since the decision of job separation may have been made two months before the actual event. Although displacement and replacement effects cannot be empirically distinguished, we assume that the timing of decision coincides with that of the observation. We also look to infer what adjustment costs are incurred by comparing the effects on the two different hazards of job change and unemployment.

The degree of substitution in employing foreign workers and natives is likely to be stronger among those with the same occupation within a firm, than among all employees of a firm. We explore this possibility by breaking down the measure of the employment of foreign workers by occupation. The share of the foreign workers in occupation $m$ in workplace $l$ in period $t$ is denoted by $F W_{l m t}=F_{I m t} /\left(N_{l m t}+F_{l m t}\right)$, and the change of the share over period $t$ and period $t+1$ by $\Delta F W_{l m t+1}=\left(F_{l m t+1}-F_{l m t}\right) /\left(N_{l m t}+F_{l m t}\right)$.

In theory, analysis at the occupation level of a workplace is superior to that at the workplace level; however, the measure of occupation may not be coded consistently across firms, and substitution among employees in different occupations is also relevant to policy discussion. Therefore, the analytical results at the two different levels are likely to be complementary. As Malchow-Møller et al. (2009) discuss, the employment of foreign workers may be endogenous to the probability of job separation: if a worker with a higher (lower) chance of leaving a job tends to choose a workplace with more foreign workers than other workers, the 
estimate on the displacement effect is likely to be biased upwards (downwards). The typical solution in the literature is to use as IVs the number of foreign workers and changes to their share in a local labor market. We consider models with IVs, and an individual fixed-effects model. $^{8}$

\section{Data Description}

The data used in analysis are drawn from the database of the NEI, one of the four major social insurance systems in Korea. The duty to cover the employees under NEI has been imposed on all the employers since $1998 .^{9}$

According to the Economically Active Population Survey, the ratio of those insured under NEI among all employees increased from $32.6 \%$ at the end of 2003 to $40.4 \%$ in 2008 . Over the same period, the ratio of the insured to paid laborers increased from $49.3 \%$ to $58.0 \%$, and the ratio of the insured to full-time and temporary laborers increased from $57.8 \%$ to $66.3 \%{ }^{10}$ Hence, although less than a half of the Korean labor force is covered by NEI, it is reasonable to assume that the NEI-insured comprise paid laborers-and, especially, full-time and temporary laborers- to a certain degree.

\footnotetext{
${ }^{8}$ Malchow-Møller et al. (2009) found that a model containing IVs produces results qualitatively identical to those of the basic model.

${ }^{9}$ There exist exceptions, based on industry and the size of the workplace. For example, an individual employer hiring fewer than five workers in agriculture, forestry, fishery, or hunting is exempt. There are also exceptions for employees; for example, it is not applied to those aged 65 years or above, or to those who work fewer than 60 hours per month.

${ }^{10}$ In the Economically Active Population Survey, the employees consist of paid laborers and nonpaid laborers. Paid laborers include full-time laborers, temporary laborers, and daily laborers. Distinctions among the three groups are based mainly on contract duration: an employee with a contract for a period longer than one year or for no specific term is categorized as a full-time laborer; for a period longer than one month and shorter than one year, as a temporary laborer; and for a period shorter than one month, as a daily laborer.
} 
The number of foreign workers among the NEI-insured, over time, are shown in $<$ Figure $2>$. In early 2004, there were around five thousands NEI-insured foreign workers-accounting for $0.06 \%$ of all insured workers—and the number increased gradually until August 2004, when EPS was established. Since then, the number of foreign workers has increased dramatically, reaching 39 thousands, or $0.48 \%$ of all NEI-insured, in December 2005. There was a sudden drop in January 2006 in the share of foreign workers, to $0.13 \%$, when their NEI coverage changed from mandatory to optional. ${ }^{11}$ Due to data availability vis-à-vis foreign workers, the analysis below relates to the August 2004-December 2005 period.

The data cover industries to which EPS is applied: agriculture and forestry, manufacturing, accommodation and food service activities, transportation, business support services, other community, repair and personal services, wholesale, and retail trade. ${ }^{12}$ Manufacturing industry workplaces are restricted to those with fewer than 300 employees; those in the construction industry are excluded, because there NEI coverage is low among foreign workers. $^{13}$

The final sample consists of all employment spells belonging to the $3 \%$ sample of NEIinsured over the August 2004-December 2005 period. ${ }^{14}$ The sample is restricted to employees aged 18-65 years, and to those workplaces with more than four employees. $<$ Table $1>$ summarizes the sample statistics at the levels of workers, job spells, and worker-

\footnotetext{
11 National Employment Insurance Act, Enforcement Ordinance Article 3.

12 The classification of industries follows the eighth revision of the Korean Standard Industrial Classification in 2000.

13 As for the manufacturing industry, EPS applies to those workplaces with (i) fewer than 300 employees or (ii) capital less than KRW8 billion (approximately USD7 million). Since the latter condition is not verified in the NEI database, only the former condition is considered.

14 The population sampled comprises all workers covered by NEI over the sample period. The average sample size in any given month is around $2.3 \%$ of all NEI-insured.
} 
months. There are around 159 thousands workers in the sample, with an average age of 37 years; one-third of them are women. In terms of education, the share of high school graduates is the largest (51\%); the shares of university graduates and college graduates are $27 \%$ and $13 \%$, respectively. The number of job spells per worker over the sample period is 1.34; this implies that one in three workers changed jobs.

The number of employment spells in the sample is around 183 thousands, and the ratios of those ending in unemployment and job change are $27.4 \%$ and $6.4 \%$, respectively. The average spell duration is 9.7 months.

As for industry distribution, the ratio of job spells in manufacturing to all job spells is $41.8 \%$, while that of agriculture and forestry is $0.5 \%$. The remaining $57.7 \%$ is broken out across various service industries. With regard to occupation, the share of clerks is the largest (28.3\%), and those of elementary occupations and craft \& related trades workers are $21.9 \%$ and $16.5 \%$, respectively. These occupation groups, together with service workers \& sales workers and technicians \& associate professionals, account for $88.3 \%$ of all job spells.

To estimate a duration model, we use the 1.77 million worker-month observations available; the monthly probability of unemployment and job change events are $2.8 \%$ and $0.7 \%$, respectively. The average tenure is 36 months. The size of the labor force at the workplace level is 507 on average, but its median is $65-\mathrm{a}$ number that implies that the distribution is highly skewed leftwards. The average share of foreign workers at the workplace level is $0.36 \%$, and its change is $0.02 \%$. The average number of workers in the same occupation within a firm is 290 persons, and the median thereof is 26; the share of foreign workers at the occupation level is $0.22 \%$. 


\section{Empirical Results}

The estimation results vis-à-vis the relationship between the employment of foreign and native workers in the workplace are presented in <Table 2>. According to column (1), the increase in the share of foreign workers lowers the probability of job separation, but the coefficients are imprecisely estimated. Both coefficients on the share of the foreign workers are positive and statistically significant at conventional levels, which implies that the characteristics of workplaces with a greater percentage of foreign workers are associated with a higher probability of employees' job separation. The correlation coefficient between the unobserved characteristics related to the transition to unemployment and job change $\left(\rho_{e u}\right)$ is estimated to be positive, suggesting that laborers with a higher chance of being unemployed are also more likely to change jobs.

Firms expanding their business are more likely to hire more natives and more foreign workers alike. When change in the total workforce is controlled for in column (2) of $<$ Table $2>$ to address this possibility, the increase in the foreign labor force at the firm level is estimated to increase the hazard of job separation, but both estimates are still imprecisely estimated. As expected, employees are less likely to leave their jobs in firms expanding their workforces.

Those employees of firms with higher shares of foreign workers may be exposed to a higher risk of job separation - that is, the working environment of firms hiring foreign workers may attract those laborers whose employment behavior is rather unstable, which is likely to cause estimation bias. To address this endogeneity issue, we need IVs that correlate with changes in the foreign workforce but not with the employment opportunities of individual native workers. 
In line with the literature-including the studies of Altonji and Card (1991) and Card (2001) — we use as IVs the ratio of the foreign residents to the local labor force by province by month, and its change. ${ }^{15}$ According to column (3) of < Table $2>$ with IV Probit hazards, the increase in the share of foreign workers increases the hazard of unemployment and decreases that of job change, but both coefficients are imprecisely estimated.

It is difficult to claim the potential endogeneity of changes in the foreign workforce at the firm level, considering that the standard error of the coefficient in the IVs model is large. Rather, this may suggest that the IVs are not valid. Given the lack of alternative IVs, the results in column (2) are principally taken, but given the possibility of upward bias, interpretation requires caution.

Next, the estimation results regarding occupation at the firm level are shown in columns (4)(6) of < Table 2>. When the change in size of the total workforce in occupation is controlled for-as in column (5) — there is substitutability between foreign and native workers in the same occupation. To be specific, a $10 \%$ increase in the share of the foreign workers in the same occupation increases the probability of unemployment by $0.12 \%$, and the estimate is statistically significant at the $10 \%$ level.

In column (6) of <Table 2>-which contains estimations with IVs for the employment of foreign workers-increases in the share of foreign labor at the occupation level lead to

\footnotetext{
${ }^{15}$ In estimations of the Probit hazard with IV, we assume the transitions to unemployment and job change to be independent events, to reduce computational burden. The two-stage estimation procedure proposed by Newey (1987) is taken. Although the correlation between unobserved characteristics related to two hazards is positive, it should be noted that its presence did not overly influence the effect of the foreign workforce on the probability of job separation (see < Table A1>).
} 
increases in the hazard of job separation, but the effects are not as precisely estimated as in the case of analysis at the firm level.

The effects of other variables are as follows. ${ }^{16}$ In model 1 of $<$ Table $2>$, as tenure increases, the probability of job separation decreases, up to 86 months in the case of unemployment and 121 months in the case of job change; it increases thereafter. Female employees tend to face a higher risk of unemployment but a lower risk of job change than male counterparts. The effect of age exhibits a nonlinear pattern, like tenure: as one ages, the hazard of job separation decreases, and then increases after 44 years in the case of unemployment and after 40 years in the case of job change. In general, those with a higher education tend to have a lower risk of unemployment than less-educated individuals; one exception is that high school graduates are more likely to be unemployed than middle school graduates. On the other hand, those with a college education or higher tend to have a higher risk of job change than those without college degrees. Finally, those employed in larger firms have a lower chance of job separation than those in smaller firms. These results are qualitatively consistent across different models.

The results in <Table 2> suggest that the overall employment of natives is not overly affected by the arrival of foreign workers in firms, but that the composition of occupation among natives adjusts. Since there is a potential positive correlation between individual heterogeneity and the characteristics of firms that hire foreign workers, the above estimates should be interpreted as an upper bound of the substitution effect.

To gauge the magnitude of bias due to individual-level heterogeneity, a fixed-effects model is estimated for the sample of employees with more than one job spell. From the total sample,

${ }^{16}$ Refer to < Table A1>. Note that column (1) in <Table 2> is identical to column (2) in < Table A1>. 
the percentage of individual workers to have more than one is $26.2 \%$; $95 \%$ of those have two or three spells. A linear hazard function is taken and the transitions to unemployment or job change are estimated separately, to facilitate comparisons of basic and fixed-effects models. Since employees with more than one job spell are likely to exhibit more unstable employment patterns than others, the results of the fixed-effects estimation are not directly comparable to those of the full sample; in analyzing this subsample, we look only to infer the direction and size of heterogeneity-generated bias.

Estimation results for the sample of employees with more than one employment spell are presented in $<$ Table $3>$. In column (1) of the basic model, the increase in the share of the foreign workers at the firm level tend to lower the risk of unemployment and increase that of job change; both coefficients are imprecisely estimated. Similar results are found when timeinvariant individual traits are removed (column (2)). At the occupation level within a workplace, on the other hand, the share of foreign labor increases the probability of unemployment and decreases that of job change, but neither estimate is statistically significant in the basic specification in column (3). In column (4), with individual fixed effects removed, the signs of the effects are the same, but the effect on the transition to unemployment is estimated precisely. Somewhat unexpectedly, the fact that the estimated effect on the risk of unemployment is larger under the fixed-effects model than the ordinary least squares (OLS) model suggests a correlation between a firm's hiring of foreign workers and unstable patterns of individual employment. However, the difference in coefficients between columns (3) and (4) is not substantial.

Comparisons of the fixed-effects and OLS models suggest that the presence of heterogeneity does generate estimation bias at the occupation level, but that its magnitude is likely small. 
Of course, the results in <Table 3> do not apply directly to the total sample. However, to the extent that laborers with more than one job spell tend to experience more unstable employment than the total sample, our inference is that bias in the total sample is likely to smaller than in the subsample.

The consequences of foreign labor on the employment of natives may differ by industry, owing to technological differences among them. Especially, we examine differences between the manufacturing and service industries. ${ }^{17}$ The estimation results of a model that allows this possibility are shown in <Table $4>$. In the manufacturing industry, there is no clear evidence of a relationship between the employment of foreign and native workers at the workplace or the occupation level of the workplace. In the service industry, however, there is a substitution effect of foreign labor at the firm level, but not at the occupation level within a firm. According to column (1) of <Table 4>, a 10\% increase in the share of foreign labor within a firm increases the probability of unemployment by $0.65 \%$. However, the effect of foreign labor at the occupation level on the hazard of job separation is imprecisely estimated in column (2). Hence, the substitution effect of the foreign workforce at the firm level is detected in the service industry but not the manufacturing industry.

Substitutability between foreign and native labor is likely to vary depending on the level of human capital among natives. Since foreign workers under EPS are categorized as lowskilled labor, the substitution effect is likely to be stronger for low-skilled natives. We explore this hypothesis by using education level as a measure of human capital.

\footnotetext{
${ }^{17}$ Those employed in agriculture and forestry are excluded from the estimation, as they comprise only $0.5 \%$ of the sample.
} 
According to column (1) of <Table 5>, the arrival of foreign workers in a firm increases the hazard of job change among university graduates, whereas no significant effect was estimated for the other education groups. Although this result diverges from theoretical expectations, it may suggest that task allocations are based on relative skill levels: it is possible that lowskilled natives move up to take the jobs of the high-skilled as foreign workers are employed. Since the hazard of unemployment among university graduates was not overly affected by the employment of foreign labor, their adjustment cost does not seem to be severe.

Analysis at the occupation level within a firm (column (2) of <Table 5>) produced results different from those at the firm level. We found a substitution effect between foreign workers and natives with middle school or lower education. Marginally speaking, a $10 \%$ increase in the share of foreign labor within the same occupation is thought to increase the probability of unemployment by $0.38 \%$.

\section{Conclusion}

This study investigated the short-term consequences of inflows of foreign labor on employment among natives in Korea. It focused on the introduction of foreign workers through EPS for the August 2004-December 2005 period, using micro-level data from Korea's NEI database. Analysis consisted of estimating a duration model of individual employment spells.

The results are summarized thus. There is no clear evidence of a substitution effect of foreign labor at the workplace level, but it was found at the occupation level within firms: a $10 \%$ increase in the share of foreign workers in the same occupation is estimated to marginally increase the monthly probability of unemployment by $0.12 \%$. This suggests that the 
occupation composition is adjusted in response to the arrival of foreign workers. Analyses of the IVs and fixed-effects approaches indicate that the potential endogeneity-based bias on the employment of foreign workers with respect to individual risk of job separation is likely to be small.

The relationship between foreign and native labor in employment is found to differ by industry and the natives' education level. The relationship exhibits some degree of substitution at the firm level in the service industry, but not in the manufacturing industry. Regarding natives' education level, the foreign workers' substitution for university graduates is detected at the firm level. Although it is theoretically unexpected, this result likely reflects compositional changes within the workforce, to the extent that only the university graduates' transition to job change is affected by the employment of foreign workers, but not the transition to unemployment. The substitution effect of foreign labor, however, is found for natives with less than a high school diploma at the occupation level within a workplace.

The overall results suggest that adjustment costs related to inflows of foreign labor under EPS were not severe between its introduction in 2004, and 2005. However, the impact of employment on natives differs by industry and by natives' education level; this implies that public policy needs to be tailored, sector by sector. Especially in the service industry, where a substitution effect is found, the employers' duty in advertising jobs needs to be carefully monitored. As a longer-term goal, relaxing service industry regulations would help employers adjust their workforces more efficiently, so that more jobs are created economy-wide. Public assistance for low-educated employees-including job training programs or job search assistance—needs to be strengthened. 
This study's contribution is that it evaluates the consequence of adopting EPS, regarding the employment of native workers at the individual level; nonetheless, this study has limitations. First, empirical analysis was performed only for the early years of EPS in Korea. Second, the employee sample is restricted to those covered by NEI; especially, through EPS, the proportion of overseas Koreans is larger than that of general foreign labor. Therefore, further research is needed to investigate the economic impacts of immigrants in a more recent period and across a more general population. Nevertheless, it is encouraging to see that Korea's EPS is largely under control, given the huge potential benefit for source countries, through remittances (World Bank, 2012). Systematic monitoring of the labor market would help make policy consistent and sustainable. 
References

Altonji, J. G. and D. Card 1991 "The Effect of Immigration on the Labor Market Outcomes of Less-Skilled Natives Immigration.” In Immigration, Trade, and the Labor Market. Ed. J. M. Abowd and R. B. Freeman. Chicago, IL: University Of Chicago Press. Pp. 201-234.

Angrist, J. D. and A. Kugler 2003 "Protective or Counter-Productive? Labor Market Institutions and the Effect of Immigration on EU Natives.” The Economic Journal 113:F302F331.

Borjas, G. J. 1999 "The Economic Analysis of Immigration.” In Handbook of Labor Economics Vol. 3. Ed. O. C. Ashenfelter and D. Card. Amsterdam, The Netherlands: Elsevier Science B.V. Pp: 1697-1760.

Borjas, G. J., R. B. Freeman, and L. F. Katz 1997 "How Much Do Immigration and Trade Affect Labor Market Outcomes?” Brookings Papers on Economic Activity 1997(1):1-90.

Card, D. 2001 "Immigrant Inflows, Native Outflows, and the Local Market Impacts of Higher Immigration.” Journal of Labor Economics 19(1):22-64.

Cho, J. 2004 "The Analysis on Substitution of Foreign Labor for the Natives." In The Analysis on the Market for the Low-skilled Foreign Labor. Ed. G. Yoo, Korea Labor Institute Report 2004-14, Pp:128-143. [in Korean]

Dustmann, C., F. Fabbri, and I. Preston 2005 "The Impact of Immigration on the British Labour Market.” The Economic Journal 115(507): F324-F341.

Hahn, C. H. and Y.-S. Choi 2006 "On the Economic Impact of Foreign Labour Inflows in Korea.” Korea Development Review 28(1): 96-116. [in Korean]

Kim, N. H.-J. 2008 "Korean Immigration Policy Changes and the Political Liberals' Dilemma.” International Migration Review 42(3): 576-596.

Lee K. and J. Park 2008 "Employment Status of Foreign Labor and Its Impact." Labor Review, 45:27-38. [in Korean].

Longhi, S., P. Nijkamp, and J. Poot 2008 "Meta-Analysis of Empirical Evidence on the Labour Market: Impacts of Immigration.” Région et Développement 27:161-191.

Malchow-Møller, N., J. R. Munch, and J. R. Skaksen 2009 “Do Immigrants Take the Jobs of Native Workers?” IZA Discussion Paper No. 4111.

Newey, W. K. 1987 "Simultaneous Estimation of Limited Dependent Variable Models with Endogenous Explanatory Variables.” Journal of Econometrics 36(3):231-250. 
OECD 2009 International Migration Outlook: SOPEMI 2007 EDITION. Paris, France: OECD Publishing, 2009.

Seol, D.-H. and J. D. Skrentny 2009 "Why Is There So Little Migrant Settlement in East Asia?” International Migration Review 43(3):578-620.

Sueyoshi, G. T. 1992 "Semiparametric Proportional Hazards Estimation of Competing Risks Models with Time-varying Covariates.” Journal of Econometrics 51:25-58.

World Bank 2012 Migration and Development Brief 19.

Yoo, G. and K. Lee 2009 Status of Foreign Workers and Policy Challenges, KDI Policy Research Series 2009-04, Korea Development Institute. [in Korean]. 
$<$ Figure $1>$ The number and the share of foreign workers covered by National Employment Insurance

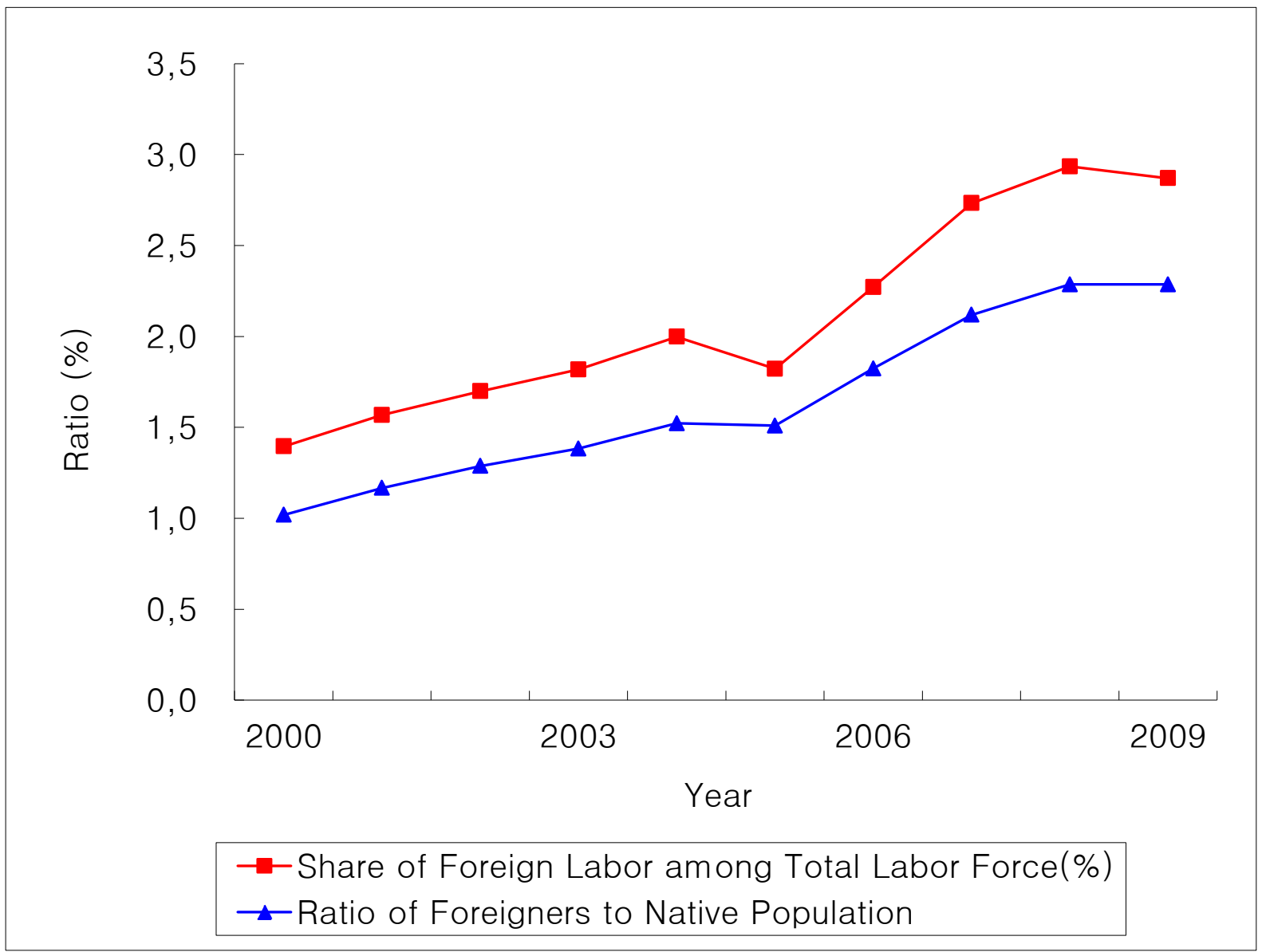


$<$ Figure 2> The number and the share of foreign workers covered by Korea's National Employment Insurance

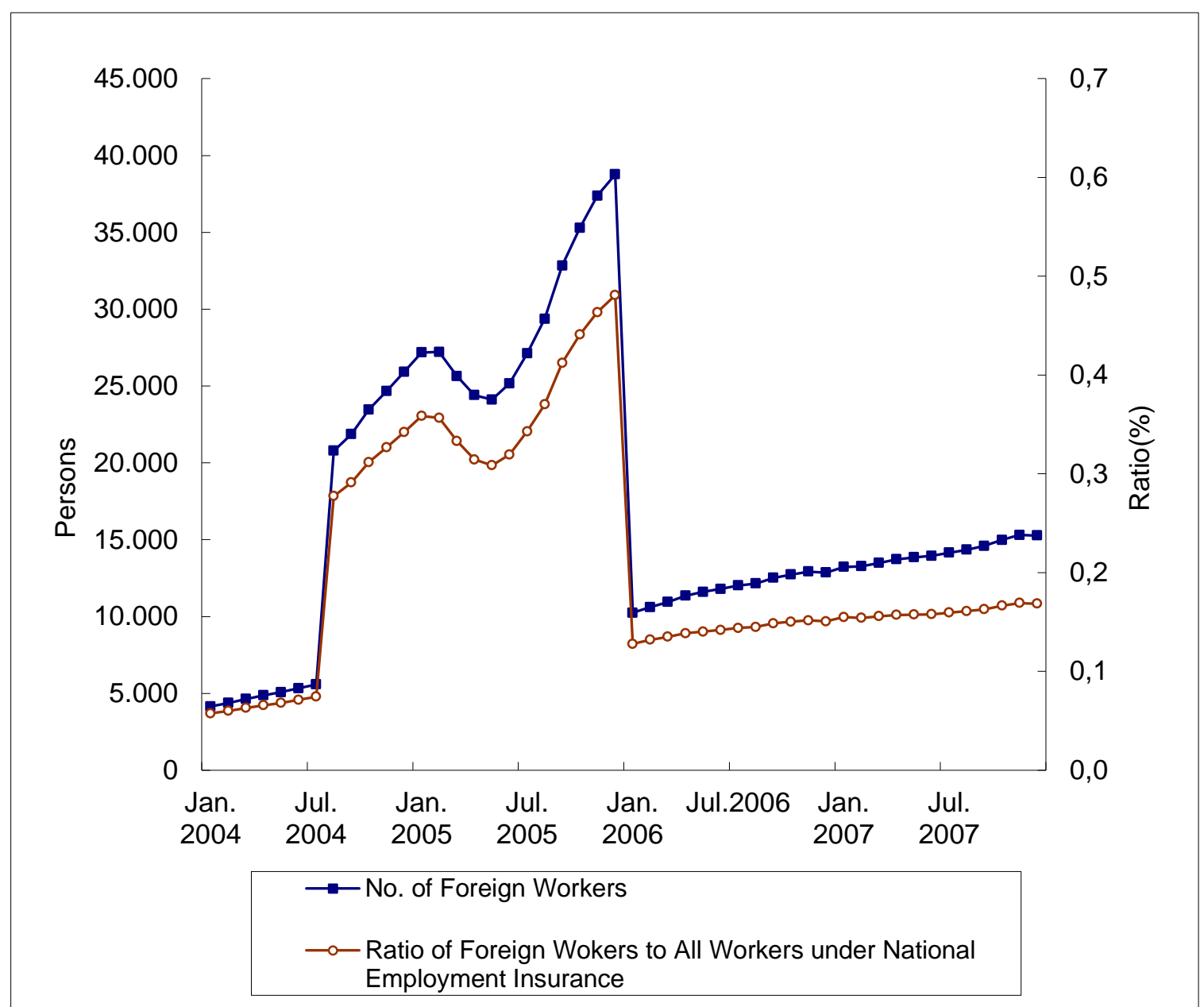

Source: National Employment Insurance Database. 
$<$ Table 1> Summary Statistics

\begin{tabular}{|c|c|c|c|c|}
\hline \multicolumn{5}{|l|}{ Sample of Employees $(N=158,805)$} \\
\hline Variables & Mean & Std. Dev. & Min. & Max. \\
\hline Female & 0.3406 & 0.4739 & 0 & 1 \\
\hline Birth Year & 1968 & 11 & 1936 & 1990 \\
\hline Education: Middle school or below & 0.0898 & 0.2860 & 0 & 1 \\
\hline Education: High school & 0.5113 & 0.4999 & 0 & 1 \\
\hline Education: 2-year College & 0.1328 & 0.3394 & 0 & 1 \\
\hline Education: University or above & 0.2660 & 0.4419 & 0 & 1 \\
\hline Number of job spells & 1.3350 & 0.6379 & 1 & 11 \\
\hline \multicolumn{5}{|l|}{ Sample of Employment Spells $(N=183,408)$} \\
\hline Variables & Mean & Std. Dev. & Min. & Max. \\
\hline Trasition of job to umemployment & 0.2742 & 0.4461 & 0 & 1 \\
\hline Trasition of job to job & 0.0643 & 0.2454 & 0 & 1 \\
\hline Tenure(months) & 9.6667 & 5.7262 & 1 & 16 \\
\hline Industry 1: Agriculture and Forestry & 0.0049 & 0.0699 & 0 & 1 \\
\hline Industry 2: Manufacturing & 0.4177 & 0.4932 & 0 & 1 \\
\hline Industry 3: Wholesale and Retail Trade & 0.1423 & 0.3494 & 0 & 1 \\
\hline Industry 4: Accommodation and Food Service Activities & 0.0315 & 0.1745 & 0 & 1 \\
\hline Industry 5: Transportation & 0.1058 & 0.3076 & 0 & 1 \\
\hline Industry 6: Business Support Service & 0.2477 & 0.4317 & 0 & 1 \\
\hline Industry 7: Other Community, Repair and Personal Services & 0.0501 & 0.2182 & 0 & 1 \\
\hline Occupation 1: Legislators, Senior Officials and Managers & 0.0243 & 0.1540 & 0 & 1 \\
\hline Occupation 2: Professionals & 0.0356 & 0.1852 & 0 & 1 \\
\hline Occupation 3: Technicians and Associate Professionals & 0.0826 & 0.2753 & 0 & 1 \\
\hline Occupation 4: Clerks & 0.2829 & 0.4504 & 0 & 1 \\
\hline Occupation 5: Service Workers \& Sales Workers & 0.1327 & 0.3392 & 0 & 1 \\
\hline Occupation 6: Skilled Agricultural, Forestry and Fishery Workers & 0.0029 & 0.0538 & 0 & 1 \\
\hline Occupation 7: Craft and Related Trades Workers & 0.1653 & 0.3715 & 0 & 1 \\
\hline Occupation 8: Plant, Machine Operators and Assemblers & 0.0544 & 0.2268 & 0 & 1 \\
\hline Occupation 9: Elementary Occupations & 0.2192 & 0.4137 & 0 & 1 \\
\hline \multicolumn{5}{|l|}{ Sample of Employee-Months $(N=1,770,913)$} \\
\hline Variables & Mean & Std. Dev. & Min. & Max. \\
\hline Transition to unemployment & 0.0284 & 0.1661 & 0 & 1 \\
\hline Transition to job change & 0.0067 & 0.0814 & 0 & 1 \\
\hline Tenure(months) & 35.8345 & 34.6690 & 1 & 124 \\
\hline Workplace: total number of employees & 507 & 1,736 & 1 & 16,469 \\
\hline Workplace: share of foreign workers & 0.0036 & 0.0258 & 0 & 1 \\
\hline Workplace: change in the share of foreign workers & 0.0002 & 0.0095 & -1 & 1 \\
\hline Workplace-Occupation: total number of employees & 290 & 1,026 & 1 & 10,358 \\
\hline Workplace-Occupation: share of foreign workers & 0.0022 & 0.0246 & 0 & 1 \\
\hline Workplace-Occupation: change in the share of foreign workers & 0.0001 & 0.0100 & -1 & 1 \\
\hline Share of the foreigners to the labor force by province & 0.0206 & 0.0065 & 0.01 & 0.03 \\
\hline Change in the share of the foreigners to the labor force by province & 0.0048 & 0.0246 & -0.07 & 0.08 \\
\hline
\end{tabular}


$<$ Table 2> Employment Effect of Inflows of Foreign Workers at Workplace Level

\begin{tabular}{|c|c|c|c|c|c|c|}
\hline \multirow[t]{2}{*}{ Explanatory Variables } & \multicolumn{2}{|c|}{$\begin{array}{c}(1) \\
\text { Workplace Level } \\
\text { (Probit) }\end{array}$} & \multicolumn{2}{|c|}{$\begin{array}{c}\text { (2) } \\
\text { Workplace Level } \\
\text { (Probit) }\end{array}$} & \multirow{2}{*}{\multicolumn{2}{|c|}{\begin{tabular}{|c|}
$\begin{array}{c}(3) \\
\text { Workplace Level } \\
\text { (Probit IV) }\end{array}$ \\
Unemployment Job Change \\
\end{tabular}}} \\
\hline & Unemployment & Job Change & Unemployment & Job Change & & \\
\hline $\begin{array}{l}\text { Change in the share of } \\
\text { the foreign workers in } \\
\text { workplace }\left(\Delta F W_{l t+1}\right)\end{array}$ & $\begin{array}{l}-0.0881 \\
(0.1909)\end{array}$ & $\begin{array}{l}-0.3517 \\
(0.3260)\end{array}$ & $\begin{array}{l}0.1044 \\
(0.1954)\end{array}$ & $\begin{array}{l}0.0870 \\
(0.3990)\end{array}$ & $\begin{array}{c}3.4150 \\
(22.8433)\end{array}$ & $\begin{array}{l}-11.0730 \\
(42.3979)\end{array}$ \\
\hline $\begin{array}{l}\text { Share of the foreign } \\
\text { workers in } \\
\text { workplace }\left(F W_{l t}\right)\end{array}$ & $\begin{array}{l}0.3923^{* * * *} \\
(0.0719)\end{array}$ & $\begin{array}{l}0.3577^{* * *} \\
(0.1228)\end{array}$ & $\begin{array}{l}0.5776^{* * * *} \\
(0.0742)\end{array}$ & $\begin{array}{l}0.542^{1 * * *} \\
(0.1349)\end{array}$ & $\begin{array}{l}23.4129^{* * *} \\
(10.9627)\end{array}$ & $\begin{array}{l}36.6531^{*} \\
(21.0788)\end{array}$ \\
\hline $\begin{array}{l}\text { Change of workforce } \\
\text { size in workplace }\end{array}$ & & & $\begin{array}{l}-3.0443^{\text {w+ate }} \\
(0.0169)\end{array}$ & $\begin{array}{l}-3.992^{* * *} \\
(0.0274)\end{array}$ & $\begin{array}{l}-3.2363^{* * * *} \\
(0.1324)\end{array}$ & $\begin{array}{l}-4.3398^{* * *} \\
(0.2638)\end{array}$ \\
\hline$\rho_{\mathrm{eu}}$ & $\begin{array}{l}0.2617^{* * *} \\
(0.068)\end{array}$ & & $\begin{array}{l}0.5730^{\text {**** }} \\
(0.0693)\end{array}$ & & & \\
\hline Log Likelihood & \multicolumn{2}{|c|}{$-282,666.02$} & \multicolumn{2}{|c|}{$-265,760.32$} & & \\
\hline No. of Observations & $1,759,111$ & $1,720,629$ & $1,759,111$ & $1,720,629$ & $1,759,111$ & $1,720,629$ \\
\hline \multirow[t]{2}{*}{ Explanatory Variables } & \multicolumn{2}{|c|}{$\begin{array}{c}\text { (4) } \\
\text { Occupation Level } \\
\text { (Probit) }\end{array}$} & \multicolumn{2}{|c|}{$\begin{array}{c}\text { (5) } \\
\text { Occupation Level } \\
\text { (Probit) }\end{array}$} & \multicolumn{2}{|c|}{$\begin{array}{c}\text { (6) } \\
\text { Occupation Level } \\
\text { (Probit IV) }\end{array}$} \\
\hline & Unemployment & Job Change & Unemployment & Job Change & Unemploymen & Job Change \\
\hline $\begin{array}{l}\text { Change in the share of } \\
\text { the foreign workers in } \\
\text { occupation }\left(\Delta F W_{l m t+1}\right. \\
\text { ) }\end{array}$ & $\begin{array}{l}0.0879 \\
(0.1418)\end{array}$ & $\begin{array}{l}-0.9212^{* *} \\
(0.4072)\end{array}$ & $\begin{array}{l}0.2494^{*} \\
(0.1370)\end{array}$ & $\begin{array}{l}-0.4041 \\
(0.5658)\end{array}$ & $\begin{array}{c}22.5681 \\
(39.1061)\end{array}$ & $\begin{array}{c}5.4037 \\
(73.2711)\end{array}$ \\
\hline $\begin{array}{l}\text { Share of the foreign } \\
\text { workers in } \\
\text { occupation }\left(F W_{l m t}\right)\end{array}$ & $\begin{array}{l}0.4956^{* * * *} \\
(0.0703)\end{array}$ & $\begin{array}{l}0.3902^{* * *} \\
(0.1199)\end{array}$ & $\begin{array}{l}0.5756^{* * * *} \\
(0.0744)\end{array}$ & $\begin{array}{l}0.5455^{* * * *} \\
(0.1316)\end{array}$ & $\begin{array}{l}39.1823^{* *} \\
(17.2423)\end{array}$ & $\begin{array}{l}59.5432^{*} \\
(32.9509)\end{array}$ \\
\hline $\begin{array}{l}\text { Change of workforce } \\
\text { size in occupation }\end{array}$ & & & $\begin{array}{l}-3.0422^{\text {wose }} \\
(0.0169)\end{array}$ & $\begin{array}{l}-3.9939^{* * * *} \\
(0.0274)\end{array}$ & $\begin{array}{l}-3.1286^{* *+*} \\
(0.0790)\end{array}$ & $\begin{array}{l}-4.1687^{* * *} \\
(0.1641)\end{array}$ \\
\hline$\rho_{\mathrm{eu}}$ & $\begin{array}{l}0.2616^{* * *} \\
(0.0679)\end{array}$ & & $\begin{array}{l}0.5767^{* * *} \\
(0.0694)\end{array}$ & & & \\
\hline Log Likelihood & \multicolumn{2}{|c|}{$-282,637.29$} & \multicolumn{2}{|c|}{$-265,747.30$} & & \\
\hline No. of Observations & $1,759,111$ & $1,720,629$ & $1,759,111$ & $1,720,629$ & $1,759,111$ & $1,720,629$ \\
\hline
\end{tabular}

Note: Explanatory variables include tenure, tenure squared, female gender, age, age squared, education level, and $\log$ of the workforce size in workplace (or occupation), as well as month dummies, industry dummies, and province dummies. The values in parentheses are asymptotic standard errors. Statistical significance: $*=10 \%$, $* *=5 \%$, $* * *=1 \%$.

Source: National Employment Insurance Database 
$<$ Table 3> Employment Effect of Inflows of Foreign Workers on Employees with More Than One Job Spell

\begin{tabular}{|c|c|c|c|c|}
\hline \multirow[t]{2}{*}{ Explanatory Variables } & \multicolumn{2}{|c|}{$\begin{array}{c}(1) \\
\text { Workplace Level } \\
\text { (OLS) }\end{array}$} & \multicolumn{2}{|c|}{$\begin{array}{c}(2) \\
\text { Workplace Level } \\
\text { (Fixed-Effects) }\end{array}$} \\
\hline & Unemployment & Job Change & Unemployment & Job Change \\
\hline $\begin{array}{l}\text { Change in the share of the foreign } \\
\text { workers in workplace }\left(\Delta F W_{l t+1}\right)\end{array}$ & $\begin{array}{l}-0.0265 \\
(0.0350)\end{array}$ & $\begin{array}{c}0.0224 \\
(0.0235)\end{array}$ & $\begin{array}{l}-0.0433 \\
(0.0359)\end{array}$ & $\begin{array}{c}0.0156 \\
(0.0255)\end{array}$ \\
\hline $\begin{array}{l}\text { Share of the foreign workers in } \\
\text { workplace }\left(F W_{l t}\right)\end{array}$ & $\begin{array}{l}0.0972 \text { *** } \\
(0.0132)\end{array}$ & $\begin{array}{l}0.0709^{* * *} \\
(0.0090)\end{array}$ & $\begin{array}{l}0.0521^{* *} \\
(0.0222)\end{array}$ & $\begin{array}{l}0.1051^{* * * *} \\
(0.0161)\end{array}$ \\
\hline Change of workforce size in workplace & $\begin{array}{l}-0.3411^{\text {sete }} \\
(0.0039)\end{array}$ & $\begin{array}{l}-0.3631^{* * *} \\
(0.0026)\end{array}$ & $\begin{array}{l}-0.3097^{*+*} \\
(0.0040)\end{array}$ & $\begin{array}{l}-0.3641^{* * * *} \\
(0.0027)\end{array}$ \\
\hline$R^{2}$ & 0.025 & 0.060 & 0.034 & 0.071 \\
\hline No. of Groups(Workers) & & & 41,457 & 40,562 \\
\hline No. of Observations & 403,084 & 390,250 & 403,084 & 390,250 \\
\hline \multirow[t]{2}{*}{ Explanatory Variables } & \multicolumn{2}{|c|}{$\begin{array}{c}\text { (3) } \\
\text { Occupation Level } \\
\text { (OLS) }\end{array}$} & \multicolumn{2}{|c|}{$\begin{array}{c}(4) \\
\text { Occupation Level } \\
\text { (Fixed-Effects) }\end{array}$} \\
\hline & Unemployment & Job Change & Unemployment & Job Change \\
\hline $\begin{array}{l}\text { Change in the share of the foreign } \\
\text { workers in occupation }\left(\Delta F W_{l m t+1}\right)\end{array}$ & $\begin{array}{c}0.0342 \\
(0.0307)\end{array}$ & $\begin{array}{l}-0.0243 \\
(0.0217)\end{array}$ & $\begin{array}{l}0.0552^{*} \\
(0.0313)\end{array}$ & $\begin{array}{l}-0.0136 \\
(0.0234)\end{array}$ \\
\hline $\begin{array}{l}\text { Share of the foreign workers in } \\
\text { occupation }\left(F W_{\text {lmt }}\right)\end{array}$ & $\begin{array}{l}0.0895^{* * *} \\
(0.0137)\end{array}$ & $\begin{array}{l}0.0582 * * * \\
(0.0093)\end{array}$ & $\begin{array}{l}0.1279 * * * \\
(0.0216)\end{array}$ & $\begin{array}{l}0.0998^{* * * *} \\
(0.0158)\end{array}$ \\
\hline Change of workforce size in occupation & $\begin{array}{l}-0.3406 * * \\
(0.0039)\end{array}$ & $\begin{array}{l}-0.3627^{m+k t} \\
(0.0026)\end{array}$ & $\begin{array}{l}-0.3098^{\text {stow }} \\
(0.0040)\end{array}$ & $\begin{array}{l}-0.3634^{* * *} \\
(0.0027)\end{array}$ \\
\hline$R^{2}$ & 0.025 & 0.060 & 0.034 & 0.072 \\
\hline No. of Groups(Workers) & & & 41,457 & 40,562 \\
\hline No. of Observations & 403,084 & 390,250 & 403,084 & 390,250 \\
\hline
\end{tabular}

Note: Explanatory variables include tenure, tenure squared, female gender, age, age squared, education level, and $\log$ of the workforce size in workplace (or occupation), as well as month dummies, industry dummies, and province dummies. The values in parentheses are asymptotic standard errors. Statistical significance: $*=10 \%, * *=5 \%$, $* * *=1 \%$.

Source: National Employment Insurance Database 
$<$ Table 4> Employment Effect of Inflows of Foreign Workers, by Industry

\begin{tabular}{|c|c|c|c|c|c|}
\hline \multirow{2}{*}{ Explanatory Variables } & \multicolumn{2}{|c|}{$\begin{array}{c}\text { (1) } \\
\text { Workplace Level }\end{array}$} & \multirow{2}{*}{ Explanatory Variables } & \multicolumn{2}{|c|}{$\begin{array}{c}\text { (2) } \\
\text { Occupation Level }\end{array}$} \\
\hline & Unemployment & $\begin{array}{l}\text { Job } \\
\text { Change }\end{array}$ & & Unemployment & $\begin{array}{c}\text { Job } \\
\text { Change }\end{array}$ \\
\hline $\begin{array}{l}\text { Change in the share of } \\
\text { the foreign workers in } \\
\text { workplace }\left(\Delta F W_{l+1}\right) \\
\text { Manufacturing Industry }\end{array}$ & $\begin{array}{l}-0.0884 \\
(0.2233)\end{array}$ & $\begin{array}{l}0.0711 \\
(0.4169)\end{array}$ & $\begin{array}{l}\text { Change in the share of } \\
\text { the foreign workers in } \\
\text { occupation }\left(\Delta F W_{\text {lmt }+1}\right) \times \\
\text { Manufacturing Industry }\end{array}$ & $\begin{array}{l}0.2052 \\
(0.1479)\end{array}$ & $\begin{array}{l}-0.5491 \\
(0.6265)\end{array}$ \\
\hline $\begin{array}{l}\text { Change in the share of } \\
\text { the foreign workers in } \\
\text { workplace }\left(\Delta F W_{l t+1}\right) \\
\text { Service Industry }\end{array}$ & $\begin{array}{l}1.2136^{* * *} \\
(0.4181)\end{array}$ & $\begin{array}{c}0.4247 \\
(1.5446)\end{array}$ & $\begin{array}{l}\text { Change in the share of } \\
\text { the foreign workers in } \\
\text { occupation }\left(\Delta F W_{\operatorname{lmt}+1}\right) \times \\
\text { Service Industry }\end{array}$ & $\begin{array}{l}0.5161 \\
(0.3824)\end{array}$ & $\begin{array}{c}0.6943 \\
(1.6698)\end{array}$ \\
\hline $\begin{array}{lr}\text { Share of the foreign } \\
\text { workers } \\
\text { workplace }\left(F W_{l t}\right) \\
\text { Manufacturing Industry }\end{array}$ & $\begin{array}{l}0.6800^{* * *} \\
(0.0794)\end{array}$ & $\begin{array}{l}0.6462^{* * *} \\
(0.1450)\end{array}$ & $\begin{array}{l}\text { Share of the foreign } \\
\text { workers } \\
\text { occupation }\left(F W_{l m}\right) \\
\text { Manufacturing Industry }\end{array}$ & $\begin{array}{l}0.6502^{* * *} \\
(0.0798)\end{array}$ & $\begin{array}{l}0.6369^{* * *} \\
(0.1407)\end{array}$ \\
\hline $\begin{array}{lr}\text { Share of the foreign } \\
\text { workers } \\
\text { workplace }\left(F W_{l t}\right) \\
\text { Service Industry }\end{array}$ & $\begin{array}{l}-0.1194 \\
(0.2175)\end{array}$ & $\begin{array}{l}-0.1939 \\
(0.4067)\end{array}$ & $\begin{array}{l}\text { Share of the foreign } \\
\text { workers } \\
\text { occupation }\left(F W_{l m t}\right) \\
\text { Service Industry }\end{array}$ & $\begin{array}{c}0.089 \\
(0.2050)\end{array}$ & $\begin{array}{l}-0.2158 \\
(0.4719)\end{array}$ \\
\hline $\begin{array}{l}\text { Change of workforce } \\
\text { size in workplace }\end{array}$ & $\begin{array}{l}-3.0446^{* * *} \\
(0.0169)\end{array}$ & $\begin{array}{l}-3.9917^{* * *} \\
(0.0274)\end{array}$ & $\begin{array}{l}\text { Change of workforce } \\
\text { size in occupation }\end{array}$ & $\begin{array}{l}-3.0424^{* * *} \\
(0.0169)\end{array}$ & $\begin{array}{r}-3.9939^{* * *} \\
(0.0274)\end{array}$ \\
\hline$\rho_{\mathrm{eu}}$ & $\begin{array}{l}0.5727^{* * *} \\
(0.0693)\end{array}$ & & $\rho_{\mathrm{eu}}$ & $\begin{array}{l}0.5769^{* * *} \\
(0.0695)\end{array}$ & \\
\hline Log Likelihood & \multicolumn{2}{|c|}{$-265,748.74$} & Log Likelihood & \multicolumn{2}{|c|}{$-265,740.68$} \\
\hline No. of Observations & $1,751,892$ & $1,713,588$ & No. of Observations & $1,751,892$ & $1,713,588$ \\
\hline
\end{tabular}

Note: Explanatory variables include tenure, tenure squared, female gender, age, age squared, education level, and $\log$ the workforce size in workplace (or occupation) as well as month dummies, industry dummies, and province dummies. The values in parentheses are asymptotic standard errors. Statistical significance: $*=10 \%, * *=5 \%$, $* * *=1 \%$.

Source: National Employment Insurance Database 
$<$ Table 5> Employment Effect of Inflows of Foreign Workers, by Education

\begin{tabular}{|c|c|c|c|c|c|}
\hline \multirow{2}{*}{$\begin{array}{l}\text { Explanatory } \\
\text { Variables }\end{array}$} & \multicolumn{2}{|c|}{$\begin{array}{c}1() \\
\text { Workplace Level } \\
\end{array}$} & \multirow{2}{*}{ Explanatory Variables } & \multicolumn{2}{|c|}{$\begin{array}{c}\text { (2) } \\
\text { Occupation Level } \\
\end{array}$} \\
\hline & Unemployment & $\begin{array}{c}\text { Job } \\
\text { Change }\end{array}$ & & Unemployment & $\begin{array}{c}\text { Job } \\
\text { Change }\end{array}$ \\
\hline $\begin{array}{l}\text { Change in the share } \\
\text { of the foreign } \\
\text { workers in } \\
\text { workplace }\left(\Delta F W_{l t+1}\right) \times \\
\text { Middle School or } \\
\text { below }\end{array}$ & $\begin{array}{l}-0.4548 \\
(0.7216)\end{array}$ & $\begin{array}{l}-3.0200 \\
(2.7374)\end{array}$ & $\begin{array}{l}\text { Change in the share of } \\
\text { the foreign workers in } \\
\text { occupation }\left(\Delta F W_{l m t+1}\right) \times \\
\text { Middle School or } \\
\text { below }\end{array}$ & $\begin{array}{l}0.8352^{* * *} \\
(0.2859)\end{array}$ & $\begin{array}{l}-1.2187 \\
(2.2847)\end{array}$ \\
\hline $\begin{array}{l}\text { Change in the share } \\
\text { of the foreign } \\
\text { workers in } \\
\text { workplace }\left(\Delta F W_{l t+1}\right) \times \\
\text { High School }\end{array}$ & $\begin{array}{r}0.1380 \\
(0.2371)\end{array}$ & $\begin{array}{l}-0.1036 \\
(0.5749)\end{array}$ & $\begin{array}{l}\text { Change in the share of } \\
\text { the foreign workers in } \\
\text { occupation }\left(\Delta F W_{l m t+1}\right) \times \\
\text { High School }\end{array}$ & $\begin{array}{l}0.0605 \\
(0.1849)\end{array}$ & $\begin{array}{l}-0.4517 \\
(0.8051)\end{array}$ \\
\hline $\begin{array}{l}\text { Change in the share } \\
\text { of the foreign } \\
\text { workers in } \\
\text { workplace }\left(\Delta F W_{l t+1}\right) \times \\
\text { College }\end{array}$ & $\begin{array}{r}0.3072 \\
(0.6699)\end{array}$ & $\begin{array}{l}-0.0848 \\
(1.2700)\end{array}$ & $\begin{array}{l}\text { Change in the share of } \\
\text { the foreign workers in } \\
\text { occupation }\left(\Delta F W_{l m t+1}\right) \times \\
\text { College }\end{array}$ & $\begin{array}{l}1.1159 \\
(1.0636)\end{array}$ & $\begin{array}{l}-1.9671 \\
(1.6975)\end{array}$ \\
\hline $\begin{array}{l}\text { Change in the share } \\
\text { of the foreign } \\
\text { workers in } \\
\text { workplace }\left(\Delta F W_{l t+1}\right) \times \\
\text { University of above }\end{array}$ & $\begin{array}{r}0.0586 \\
(0.4995)\end{array}$ & $\begin{array}{l}1.2077^{*} \\
(0.7071)\end{array}$ & $\begin{array}{l}\text { Change in the share of } \\
\text { the foreign workers in } \\
\text { occupation }\left(\Delta F W_{\operatorname{lmt}+1}\right) \times \\
\text { University or above }\end{array}$ & $\begin{array}{l}0.4424 \\
(0.3824)\end{array}$ & $\begin{array}{l}1.1225 \\
(1.1601)\end{array}$ \\
\hline $\begin{array}{l}\text { Share of the foreign } \\
\text { workers in } \\
\text { workplace }\left(F W_{l t}\right) \times \\
\text { Middle School or } \\
\text { below }\end{array}$ & $\begin{array}{l}0.7427^{* * *} \\
(0.2698)\end{array}$ & $\begin{array}{c}0.3869 \\
(0.5695)\end{array}$ & $\begin{array}{l}\text { Share of the foreign } \\
\text { workers in } \\
\text { occupation }\left(F W_{l m t}\right) \times \\
\text { Middle School or } \\
\text { below }\end{array}$ & $\begin{array}{l}0.3885 \\
(0.2512)\end{array}$ & $\begin{array}{l}0.2126 \\
(0.6170)\end{array}$ \\
\hline $\begin{array}{l}\text { Share of the foreign } \\
\text { workers in } \\
\text { workplace }\left(F W_{l t}\right) \times \\
\text { High School }\end{array}$ & $\begin{array}{l}0.5377^{* * *} \\
(0.0884)\end{array}$ & $\begin{array}{l}0.5238^{* * *} \\
(0.1642)\end{array}$ & $\begin{array}{l}\text { Share of the foreign } \\
\text { workers in } \\
\text { occupation }\left(F W_{l m t}\right) \times \\
\text { High School }\end{array}$ & $\begin{array}{l}0.6092^{* * *} \\
(0.0847)\end{array}$ & $\begin{array}{l}0.5616^{* * *} \\
(0.1610)\end{array}$ \\
\hline $\begin{array}{l}\text { Share of the foreign } \\
\text { workers in } \\
\text { workplace }\left(F W_{l t}\right) \times \\
\text { College }\end{array}$ & $\begin{array}{l}0.7618^{* * *} \\
(0.2269)\end{array}$ & $\begin{array}{l}0.7715^{*} \\
(0.3938)\end{array}$ & $\begin{array}{l}\text { Share of the foreign } \\
\text { workers in } \\
\text { occupation }\left(F W_{l m t}\right) \times \\
\text { College }\end{array}$ & $\begin{array}{l}0.6681^{* *} \\
(0.2860)\end{array}$ & $\begin{array}{l}0.6534^{*} \\
(0.3486)\end{array}$ \\
\hline $\begin{array}{l}\text { Share of the foreign } \\
\text { workers in } \\
\text { workplace }\left(F W_{l t}\right) \times \\
\text { University or above }\end{array}$ & $\begin{array}{l}0.5476^{* * *} \\
(0.2093)\end{array}$ & $\begin{array}{c}0.4060 \\
(0.3282)\end{array}$ & $\begin{array}{l}\text { Share of the foreign } \\
\text { workers in } \\
\text { occupation }\left(F W_{l m t}\right) \times \\
\text { University }\end{array}$ & $\begin{array}{c}0.3228 \\
(0.2656)\end{array}$ & $\begin{array}{c}0.4271 \\
(0.4064)\end{array}$ \\
\hline $\begin{array}{l}\text { Change of workforce } \\
\text { size in workplace }\end{array}$ & $\begin{array}{c}-3.0456^{* * * *} \\
(0.0169)\end{array}$ & $\begin{array}{l}-3.993^{* * *} \\
(0.0274)\end{array}$ & $\begin{array}{l}\text { Change of workforce } \\
\text { size in occupation }\end{array}$ & $\begin{array}{c}-3.0433^{* * *} \\
(0.0169)\end{array}$ & $\begin{array}{c}-3.9949^{* * *} \\
(0.0275)\end{array}$ \\
\hline$\rho_{\mathrm{eu}}$ & $\begin{array}{l}0.5740^{* * *} \\
(0.0695)\end{array}$ & & $\rho_{\mathrm{eu}}$ & $\begin{array}{l}0.5759^{* * *} \\
(0.0693)\end{array}$ & \\
\hline Log Likelihood & \multicolumn{2}{|c|}{$-265,756.64$} & Log Likelihood & \multicolumn{2}{|c|}{$-265,741.78$} \\
\hline No. of Observations & $1,759,111$ & $1,720,629$ & No. of Observations & $1,759,111$ & $1,720,629$ \\
\hline
\end{tabular}

Note: Explanatory variables include tenure, tenure squared, female gender, age, age squared, education level, and $\log$ of the workforce size in workplace (or occupation), as well as month dummies, industry dummies, and province dummies. The values in parentheses are asymptotic standard errors. Statistical significance: $*=10 \%, * *=5 \%$, $* * *=1 \%$. 
Source: National Employment Insurance Database

\section{Appendix}

<Table A1> Separate vs. Joint Estimation of Competing Risks Model (Probit Hazard)

\begin{tabular}{|c|c|c|c|c|}
\hline \multirow{2}{*}{ Explanatory Variables } & \multicolumn{2}{|c|}{$\begin{array}{c}\text { (1) } \\
\text { Separate Estimation }\end{array}$} & \multicolumn{2}{|c|}{$\begin{array}{c}\text { (2) } \\
\text { Joint Estimation }\end{array}$} \\
\hline & Unemployment & Job Change & Unemployment & Job Change \\
\hline $\begin{array}{l}\text { Change in the share of the } \\
\text { foreign workers in } \\
\text { workplace }\left(\Delta F W_{i t+1}\right)\end{array}$ & $\begin{array}{l}-0.1043 \\
(0.1829)\end{array}$ & $\begin{array}{l}-0.3554 \\
(0.3175)\end{array}$ & $\begin{array}{l}-0.0881 \\
(0.1909)\end{array}$ & $\begin{array}{l}-0.3517 \\
(0.3260)\end{array}$ \\
\hline $\begin{array}{l}\text { Share of the foreign } \\
\text { workers in } \\
\text { occupation }\left(F W_{i t}\right)\end{array}$ & $\begin{array}{l}0.3732^{* * *} \\
(0.0656)\end{array}$ & $\begin{array}{l}0.3479^{* * *} \\
(0.1189)\end{array}$ & $\begin{array}{l}0.3923^{* * *} \\
(0.0719)\end{array}$ & $\begin{array}{l}0.3577^{* * *} \\
(0.1228)\end{array}$ \\
\hline Tenure(months) & $\begin{array}{l}-0.0188^{* * *} \\
(0.0002)\end{array}$ & $\begin{array}{l}-0.0102^{* * *} \\
(0.0004)\end{array}$ & $\begin{array}{l}-0.0180^{* * *} \\
(0.0003)\end{array}$ & $\begin{array}{c}-0.0096^{* * *} \\
(0.0004)\end{array}$ \\
\hline Tenure squared/100 & $\begin{array}{l}0.0109^{* * *} \\
(0.0002)\end{array}$ & $\begin{array}{l}0.0042^{* * *} \\
(0.0004)\end{array}$ & $\begin{array}{l}0.0100^{* * *} \\
(0.0002)\end{array}$ & $\begin{array}{l}0.0037^{* * *} \\
(0.0004)\end{array}$ \\
\hline Female & $\begin{array}{l}0.0387^{* * *} \\
(0.0042)\end{array}$ & $\begin{array}{l}-0.0599^{* * *} \\
(0.0076)\end{array}$ & $\begin{array}{l}0.0444^{* * *} \\
(0.0048)\end{array}$ & $\begin{array}{c}-0.0601^{* * *} \\
(0.0079)\end{array}$ \\
\hline Age & $\begin{array}{l}-0.0617^{* * *} \\
(0.0012)\end{array}$ & $\begin{array}{l}-0.0096^{* * *} \\
(0.0023)\end{array}$ & $\begin{array}{l}-0.0698^{* * *} \\
(0.0014)\end{array}$ & $\begin{array}{l}-0.0117^{* * *} \\
(0.0024)\end{array}$ \\
\hline Age squared/100 & $\begin{array}{l}0.0696 \text { *** } \\
(0.0015)\end{array}$ & $\begin{array}{l}0.0118^{* * *} \\
(0.0028)\end{array}$ & $\begin{array}{l}0.0787^{* * *} \\
(0.0018)\end{array}$ & $\begin{array}{l}0.0142^{* * *} \\
(0.0030)\end{array}$ \\
\hline Education: High School & $\begin{array}{l}0.0330^{* * *} \\
(0.0079)\end{array}$ & $\begin{array}{c}0.0023 \\
(0.0139)\end{array}$ & $\begin{array}{l}0.0357^{* * *} \\
(0.0089)\end{array}$ & $\begin{array}{c}0.0034 \\
(0.0146)\end{array}$ \\
\hline Education: College & $\begin{array}{l}-0.0718^{* * * *} \\
(0.0096)\end{array}$ & $\begin{array}{l}0.0468^{* * *} \\
(0.0166)\end{array}$ & $\begin{array}{l}-0.0801^{* * *} \\
(0.0109)\end{array}$ & $\begin{array}{l}0.0464^{* * *} \\
(0.0174)\end{array}$ \\
\hline $\begin{array}{l}\text { Education: University of } \\
\text { above }\end{array}$ & $\begin{array}{l}-0.1400^{* * *} \\
(0.0090)\end{array}$ & $\begin{array}{l}0.0430^{* * *} \\
(0.0154)\end{array}$ & $\begin{array}{l}-0.1544^{* * *} \\
(0.0101)\end{array}$ & $\begin{array}{l}0.0427^{* * *} \\
(0.0161)\end{array}$ \\
\hline $\begin{array}{l}\text { Log workforce size in } \\
\text { workplace }\end{array}$ & $\begin{array}{l}-0.0295^{* * * *} \\
(0.0013)\end{array}$ & $\begin{array}{l}-0.0088^{* * *} \\
(0.0022)\end{array}$ & $\begin{array}{l}-0.0330^{* * *} \\
(0.0014)\end{array}$ & $\begin{array}{l}-0.0103^{* * *} \\
(0.0023)\end{array}$ \\
\hline$\sigma_{\mathrm{u}}$ & & & $\begin{array}{l}0.2885^{* * *} \\
(0.0076)\end{array}$ & \\
\hline$\sigma_{\mathrm{e}}$ & & & $\begin{array}{l}0.1983^{* * *} \\
(0.0157)\end{array}$ & \\
\hline$\rho_{\mathrm{eu}}$ & & & $\begin{array}{l}0.2617^{* * *} \\
(0.0680)\end{array}$ & \\
\hline Log Likelihood & \multicolumn{2}{|c|}{$-282,907.30$} & \multicolumn{2}{|c|}{$-282,666.02$} \\
\hline No. of Observations & $1,759,111$ & $1,720,629$ & $1,759,111$ & $1,720,629$ \\
\hline
\end{tabular}

Note: Explanatory variables include month dummies, industry dummies, and province dummies. The values in parentheses are asymptotic standard errors. Statistical significance: $*=10 \%$, $* *=5 \%, * * *=1 \%$.

Source: National Employment Insurance Database 